\title{
Doppler flowmetry of ophthalmic arteries for prediction of pre-eclampsia
}

\author{
Larissa Oliveira de Aquino ${ }^{1}$, Henrique Vítor leite ${ }^{2}$, Antônio Carlos Vieira Cabral ${ }^{3}$, Augusto Henriques F. Brandão ${ }^{4 *}$ \\ ${ }^{1}$ Physician at the Hospital das Clínicas, Federal University of Minas Gerais, Belo Horizonte, MG, Brazil \\ ${ }^{2}$ Adjunct Professor at the Department of Gynecology and Obstetrics, Federal University of Minas Gerais, Belo Horizonte, MG, Brazil \\ ${ }^{3}$ Full Professor at the Department of Gynecology and Obstetrics, Federal University of Minas Gerais, Belo Horizonte, MG, Brazil \\ ${ }^{4}$ Professor at the Postgraduate Program in Women's Health, Federal University of Minas Gerais, Belo Horizonte, MG, Brazil
}

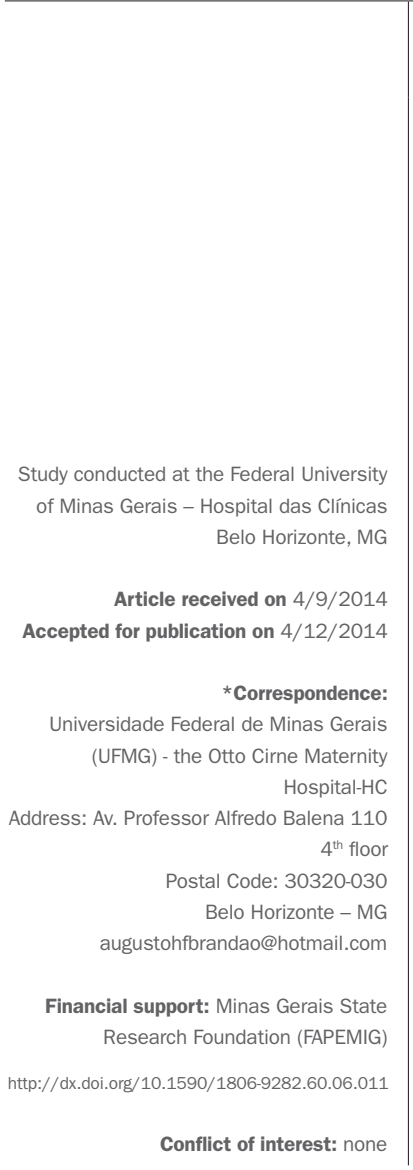

\section{SUMMARY}

Background: central nervous system (CNS) hyperperfusion is one of the events that constitute the pathophysiological basis for the clinical manifestations and complications of pre-eclampsia (PE). Detecting the increased flow in the CNS through Doppler flowmetry of the ophthalmic artery might precede the clinical onset of PE and could be used as a marker for subsequent development of PE.

Objective: to evaluate the ophthalmic artery resistive index (OARI) values in the second trimester of pregnancy for prediction of the clinical manifestations of PE. Methods: a total of 73 patients with risk factors for the development of PE were selected from the prenatal service at the HC-UFMG. They were submitted to ophthalmic artery Doppler flowmetry between 24 and 28 weeks of pregnancy and monitored until the end of the pregnancy to verify the occurrence of PE. ROC curves were created to determine the predictive characteristics of the OARI.

Results: fourteen of the patients selected developed PE and 59 remained normotensive until the postpartum period. Patients with subsequent development of PE presented OARI values lower than patients that remained normotensive $(0.682 \pm 0.028 \times 0.700 \pm 0.029, \mathrm{p}=0.044)$. Considering the development of $\mathrm{PE}$ as an outcome, the area under the OARI curve was 0.694 (CI 0.543 to 0.845 ), with no points obtaining good values of sensitivity or specificity.

Conclusion: Doppler flowmetry of ophthalmic arteries between 24 and 28 weeks of pregnancy did not present itself as a good exam for predicting PE.

Keywords: vascular endothelium, pre-eclampsia, hypertension, laser Doppler flowmetry.

\section{INTRODUCTION}

Hypertensive disorders in pregnancy are considered a major cause of maternal mortality, particularly in developing countries, including Brazil. ${ }^{1}$ Pre-eclampsia (PE) is a syndrome of multifactorial etiology, ${ }^{1}$ and its comorbidities account for a significant portion of these deaths, justifying major investment in research aiming to predict the clinical manifestations and complications of PE. ${ }^{2}$

Despite being considered a disease of the second half of the pregnancy, since the clinical manifestations of PE occur only after the twentieth week, the pathophysiological process of this syndrome begins early in the pregnancy, ${ }^{3}$ and alterations may be identified from the first gestational trimester. ${ }^{4}$ Assessing these events is of immense clini- cal interest given that, if detected, they can be considered as markers of increased risk for developing this disease. ${ }^{5}$

Although its etiology is unknown, accumulated evidence implies that the placenta is the first site in the genesis of pre-eclampsia. ${ }^{6}$ An exacerbated inflammatory process associated with local oxidative stress causes impairment of the placental angiogenesis process, preventing proper trophoblast invasion and remodeling of the uterine spiral arteries. ${ }^{7}$

The first and most studied of these events was placental perfusion, assessed using Doppler flowmetry of the uterine arteries ${ }^{3}$. With increased knowledge about other pathophysiological processes, such as endothelial 
dysfunction and hyperperfusion of the central nervous system (CNS), new perspectives have emerged. ${ }^{8}$

In the CNS, endothelial injury alters the self-regulating blood flow system in this region, which culminates in hyperflow and cerebral edema, a direct cause of tonic-clonic seizures that characterize eclampsia. ${ }^{9}$

The assessment of CNS perfusion can be realized indirectly by Doppler flowmetry of the ophthalmic artery, using its resistance index (RI). Patients with signs of central hyperflow present a lower resistance index compared to normotensive patients. ${ }^{10}$

This study has the objective of assessing the ophthalmic artery resistive index (OARI) values in the second trimester of pregnancy for the prediction of the clinical manifestations of PE.

\section{Materials AND Methods}

\section{Patients}

A total of 73 pregnant women between 24 and 28 weeks that presented risk factors for the development of PE were selected by the Prenatal Service at the Hospital das Clínicas, Federal University of Minas Gerais. Subsequently, they were submitted to Doppler flowmetry of the ophthalmic arteries and were monitored up to the postpartum period for the diagnosis of PE.

PE diagnosis was performed according to criteria defined by the National High Blood Pressure Education Program Working Group on High Blood Pressure in Pregnancy, 2000. According to this classification, PE is defined as high blood pressure after 20 weeks of pregnancy (blood pressure $\geq 140 \times 90 \mathrm{mmHg}$ for two measurements with an interval of six hours), accompanied by proteinuria (one or more on the proteinuria strip or 24 hour proteinuria> $0.3 \mathrm{~g}){ }^{11}$

All of the patients selected presented risk factors for the development of PE. 26 (35.6\%) had a history of developing early PE (before 34 weeks of pregnancy); $18(24.7 \%)$ were primigravidae with a family history of PE; 21 (28.8\%) were primigravidae and obese (pre-pregnancy body mass index greater than $\left.35 \mathrm{Kg} / \mathrm{m}^{2}\right) ; 8(10.9 \%)$ were suffering from diabetes mellitus before pregnancy.

Patients with comorbidities such as chronic hypertension, kidney failure, heart diseases and infectious diseases were excluded.

The study was approved by the Research Ethics Committee of the Federal University of Minas Gerais' Hospital das Clínicas (HC-UFMG). The patients selected to participate in the study were informed at the time of collection and signed the free and informed consent form.
After consenting, the patients were submitted to the Doppler flowmetry exam of the ophthalmic arteries between 24 and 28 weeks of pregnancy. All of the exams were conducted by the same professional at the HC-UFMG, trained and certificate in ultrasonography.

\section{Doppler flowmetry of the ophthalmic arteries}

The color Doppler imaging of the orbit was obtained from a trained examiner blinded for the clinical information of the patients. The exams were conducted using a high resolution, color Doppler scanner, the Medison 8800 with a $7.5 \mathrm{MHz}$ linear transducer, applied to closed eyes covered with methylcellulose gel. The exams were conducted with the patient in supine position, with an average duration of five minutes. A complete evaluation of the vessels of the orbit was obtained, identifying the ophthalmic artery and its branches. The anterior branch of the ophthalmic artery was assessed, approximately $10 \mathrm{~mm}$ from the posterior wall of the sclera, nasal location in relation to the optic nerve. The OARI was obtained from the right eye of the patients, after a minimum cycle of three consecutive similar waves.

\section{Statistical analysis}

All of the numerical variables were explored to verify the normality criteria of the sample. Comparisons between the 2 groups (patients who developed PE and patients who remained normotensive) were performed using Student's $t$-test for parametric samples and the Mann-Whitney U test for nonparametric samples. Differences were considered with statistical significance when $p<0.05$.

An ROC curve was created to determine the sensitivity and specificity values of the OARI in predicting PE. To create the curve, the lower the values encountered, the more positive the test was considered.

\section{Results}

Fourteen of the patients selected developed PE and 59 remained normotensive until the postpartum period. Demographic characteristics relating to pregnancy and OARI values for both groups (patients who subsequently developed PE and patients who remained normotensive) are expressed in Table 1. Patients with subsequent development of PE presented OARI values lower than patients that remained normotensive $(0.682 \pm 0.028 \times 0.700 \pm 0.029$, $\mathrm{p}=0.044)$. Considering the development of $\mathrm{PE}$ as an outcome, the area under the OARI curve was 0.694 (CI 0.543 to 0.845 ) (Figure 1), with no points obtaining good values of sensitivity or specificity (Table 2). 
TABLE 1 Characteristics of the groups of patients that developed pre-eclampsia and who remained normotensive

\begin{tabular}{|c|c|c|c|}
\hline & Normotensive & Pre-eclampsia & p Value \\
\hline Mother's age (years) & $28.5 \pm 5.9$ & $30.2 \pm 4.8$ & $\mathrm{~ns}^{*}$ \\
\hline Pregnancies & $2.3 \pm 1.7$ & $2.9 \pm 1.5$ & $\mathrm{~ns}^{* *}$ \\
\hline Pre-pregnancy weight $(\mathrm{Kg})$ & $63.6 \pm 14.8$ & $65.8 \pm 12.4$ & $\mathrm{~ns}^{* *}$ \\
\hline Body Mass Index $\left(\mathrm{Kg} / \mathrm{m}^{2}\right)$ & $23.87 \pm 5.63$ & $24.75 \pm 4.45$ & $\mathrm{~ns}^{* *}$ \\
\hline Mean arterial pressure between 24 and 28 weeks & $83.50 \pm 7.46$ & $88.57 \pm 7.81$ & $\mathrm{~ns}^{*}$ \\
\hline Gestational age of delivery (weeks) & $39.3 \pm 1.1$ & $35.1 \pm 2.0$ & $\mathrm{p}<0.001^{* *}$ \\
\hline Weight of the newborn $(\mathrm{Kg})$ & $3102.74 \pm 268.37$ & $2505.00 \pm 588.47$ & $\mathrm{P}=0.003 * *$ \\
\hline Ophthalmic artery resistive index between 24 and 28 weeks & $0.700 \pm 0.029$ & $0.682 \pm 0.028$ & $\mathrm{P}=0.044^{*}$ \\
\hline
\end{tabular}

$n s=$ not significant. ${ }^{*}$ Student's $t$ test ** Mann-Whitney $U$ test

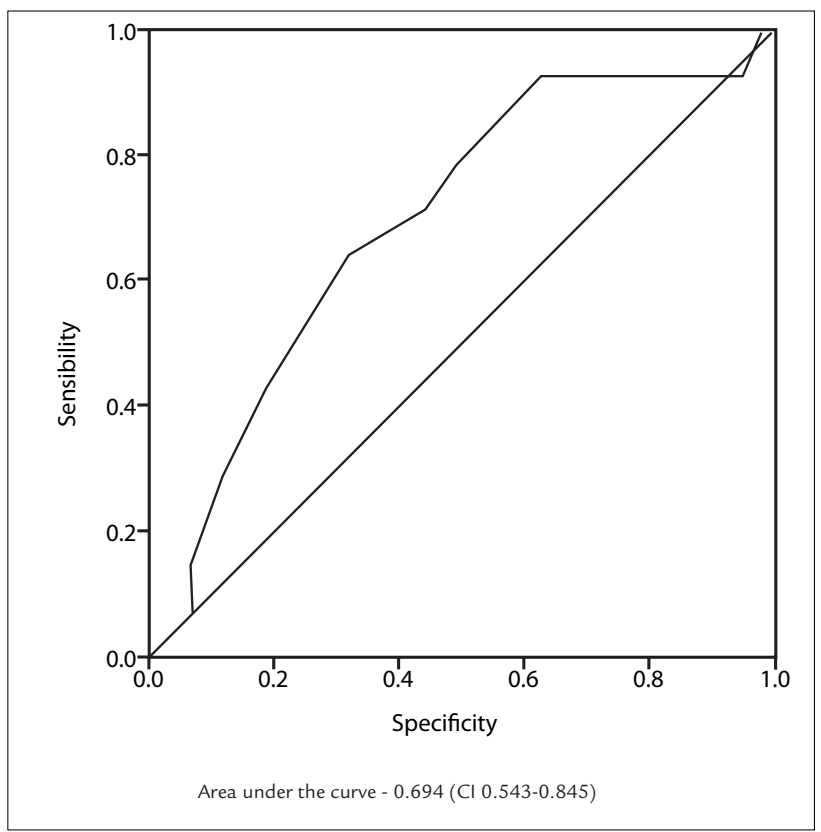

FIGURE 1 ROC Curve - Ophthalmic Artery Resistive Index between 24 and 28 weeks of pregnancy and prediction of pre-eclampsia.

\section{Discussion}

Damage to the vascular endothelium, clinically characterized as endothelial dysfunction, has been extensively demonstrated in patients with PE by means of biophysical methods, particularly testing for brachial artery flow-mediated vasodilation (FDM). ${ }^{12,13}$ Abnormal values in this test have been demonstrated in patients who subsequently developed PE, indicating that the test can be used to predict the clinical manifestations of $\mathrm{PE}$ and thus the endothelium injuries precede the clinical manifestations of the disease. ${ }^{14,15}$

Endothelial dysfunction precedes the clinical manifestations of PE and persists up to one year after childbirth, which also generates the pathophysiological basis for explaining the higher incidence of cardiovascular complications in women with a history of PE. ${ }^{16}$ Hyperperfusion of
TABLE 2 Values of sensitivity and specificity for predicting pre-eclampsia with the ophthalmic artery resistive index (OARI) between 24 and 28 weeks of pregnancy

\begin{tabular}{l|l|l} 
OARI cutoff value & Sensitivity $(\%)$ & Specificity $(\%)$ \\
\hline 0.65 & 7 & 93 \\
\hline 0.66 & 14 & 93 \\
\hline 0.67 & 29 & 88 \\
\hline 0.68 & 43 & 81 \\
\hline 0.69 & 64 & 68 \\
\hline 0.70 & 71 & 56 \\
\hline 0.71 & 79 & 51 \\
\hline 0.72 & 93 & 37 \\
\hline 0.73 & 93 & 22 \\
\hline 0.74 & 93 & 8 \\
\hline 0.75 & 93 & 5 \\
\hline 0.76 & 100 & 2 \\
\hline
\end{tabular}

the CNS, expressed by lower OARI values, has also been demonstrated in patients with PE. ${ }^{17}$

In a cross-sectional analysis of 81 patients, 56 with $\mathrm{PE}$ and 25 healthy, it was noted that the ophthalmic artery resistance index (OARI) was lower in patients with the disease in both clinical forms of presentation: late or early onset. ${ }^{8}$

Another study ${ }^{18}$ assessed 74 patients between 24 and 28 weeks of pregnancy with a high risk of development of PE. At these gestational ages, no significant difference was found in the OARI values between patients who subsequently developed and who did not develop PE. However, the same study found a higher mean PI of the uterine arteries and lower FMD among women who had PE. The authors suggest that chronologically, the CNS hy- 
perflow is the latest change in the pathophysiology of $\mathrm{PE}$, succeeding placental insufficiency and endothelial injury.

In this study, patients with subsequent development of PE presented OARI values lower than patients that remained normotensive $(0.682 \pm 0.028 \times 0.700 \pm 0.029, \mathrm{p}=0.044)$. This fact has also been demonstrated by Oliveira at al. ${ }^{19}$ when comparing 30 women with mild PE, 30 women with severe PE, 30 women with chronic hypertension and a control group of 289 normotensive pregnant women, with both groups between 20 and 40 weeks of pregnancy.

The ROC curve obtained with OARI values between 24 and 28 weeks of pregnancy did not present good results for sensitivity and specificity. Despite being significant, the difference between the two groups studied may not have been sufficient to discriminate a specific risk group. This fact can be explained by the heterogeneity of the etiology and manifestations of PE, or even the chronology of pathological events previously proposed. ${ }^{18}$

\section{Conclusion}

The present study demonstrated that the Doppler flowmetry of ophthalmic artery was not a good method for predicting clinical manifestations of $\mathrm{PE}$, supporting the hypothesis that the hyperflow of the CNS is also a late manifestation of the syndrome.

\section{Resumo}

Dopplerfluxometria de artérias oftálmicas para predição de pré-eclâmpsia.

Introdução: a hiperperfusão do sistema nervoso central (SNC) é um dos eventos que constitui substrato fisiopatológico para as manifestações clínicas e complicações da pré-eclâmpsia (PE). O fluxo aumentado no SNC, detectado por meio da dopplerfluxometria de artérias oftálmicas, poderia anteceder as manifestações clínicas da PE e, consequentemente, ser utilizado como marcador de subsequente desenvolvimento de PE.

Objetivo: avaliar os valores do índice de resistência das artérias oftálmicas (Irao) no segundo trimestre gestacional para a predição das manifestações clínicas da PE. Métodos: 73 pacientes com fatores de risco para desenvolvimento de PE foram selecionadas no serviço de pré-natal do Hospital das Clínicas da Universidade Federal de Minas Gerais (HC-UFMG). Elas foram submetidas à dopplerfluxometria de artérias oftálmicas entre 24 e 28 semanas de gestação e acompanhadas até o final da gestação para averiguar a ocorrência de PE. Curvas ROC foram criadas para determinar as características preditivas do Irao.
Resultados: das pacientes selecionadas, 14 desenvolveram PE e 59 mantiveram-se normotensas até o puerpério. Pacientes com subsequente desenvolvimento de PE apresentaram valores de Irao menores do que pacientes que se mantiveram normotensas $(0,682 \pm 0,028 v$ s. $0,700 \pm 0,029, \mathrm{p}=0,044)$. Ao considerar o desenvolvimento de $\mathrm{PE}$ como desfecho, a área sobre a curva do Irao foi de 0,694 (IC 0,543-0,845), sem pontos com bons valores de sensibilidade ou especificidade. Conclusão: a dopplerfluxometria de artérias oftálmicas entre 24 e 28 semanas de gestação não se demonstrou um bom exame para a predição de PE.

Palavras-chave: endotélio vascular; pré-eclâmpsia; hipertensão; fluxometria por laser-Doppler.

\section{References}

1. World Health Organization. The World Health Report 2005 - make every mother and childcount. Geneva: World Health Organization; 2005.

2. Roberts JM, Gammill HS. Preeclampsia: recente insights. Hypertension. 2005;46:1243-9.

3. Cabral ACV, Cabral MA, Brandão A, et al. Aspectos atuais da fisiopatologia da pré-eclâmpsia com repercussões na conduta. Femina. 2009;37(2):305-8.

4. Plasencia W, Maiz N, L. Poon L, C. Yu C, Nicolaides NH. Uterine artery Doppler at 11.0 to 13.6 weeks and 21.0 to 24.6 weeks in the prediction of pre-eclampsia. Ultrasound Obstet Gynecol. 2008;32(2):138-46.

5. Barton JR, Sibai BM. Prediction and prevention of recurrent preeclampsia. Obstet Gynecol. 2008;112(2 part 1):359-72.

6. Huppertz B. Placental origins of preeclampsia: challenging the current hypothesis. Hypertension. 2008;51(4):970-5.

7. Davison JM, Homuth V, Jeyabalan A, et al. "New aspects in the pathophysiology of preeclampsia. J Am Soc Nephrol. 2004;15(9):2440-8.

8. Brandão AHF, Barbosa AS, Lopes APBM, Leite HV, Cabral ACV. Dopplerfluxometry of ophthalmic arteries and assessment of endotelial function in early and late preeclampsia. Radiol Bras. 2012;45(1):20-3.

9. Young BC, Levine RJ, Karumanchi SA. Pathogenesis of preeclampsia. Annu Rev Pathol. 2010;5:173-92.

10. Diniz AL, Moron AF, dos Santos MC, Sass N, Pires CR, Deb CL. Ophthalmic artery Doppler as a measure of severe preeclampsia. Int J Gynaecol Obstet. 2008;100(3):216-20.

11. Report of the National High Blood Pressure Education Program Working Group on High Blood Pressure in Pregnancy. AmJ Obstet Gynecol. 2000;183:S1-S22.

12. Sierra-Laguado J, Garcia RG, López-Jaramillo P. Flow-mediated dilatation of the brachial artery in pregnancy. Int J Gynaecol Obstet. 2006;93(1):60-1.

13. Brandão AHF, Lopes APBM, Salomão CMN, et al. Dilatação fluxo-mediada da artéria braquial como método de avaliação da função endotelial na pré-eclâmpsia e em gestantes normotensas. Rev Med Minas Gerais. 2011;09:09 PM-13.

14. Takase B, Goto T, Hamabe A, et al. Flow-mediated dilation in brachial artery in the second half of pregnancy and prediction of pre-eclampsia. J Hum Hypertens. 2003; 17:697-704.

15. Savvidou MD, Noori M, Anderson JM, et al. Maternal endothelial function and serum concentrations of placental growth factor and soluble endoglin in women with abnormal placentation. Ultrasound Obstet Gynecol. 2008;32:871-6.

16. Hamad RR, Eriksson MJ, Silveira A, et al. Decreased flow-mediated dilation is present 1 year after a pre-eclamptic pregnancy. J Hypertens. 2007;25:2301-7.

17. Barbosa AS, Pereira AK, Reis ZSN, et al. Ophthalmic artery-resistive index and evidence of overperfusion-related encephalopathy in severe preeclampsia. Hypertension. 2010;55:189-93.

18. Brandão AH, Cabral MA, Leite HV, Cabral AC. Endothelial function, uterine perfusion and central flow in pregnancies complicated by preeclampsia. Arq Bras Cardiol. 2012t;99(4):931-5.

19. Oliveira CA, Sá RA, Valverde LG. Changes in ophthalmic artery Doppler indices in hypertensive disorders during pregnancy. 2013. American Institute of Ultrasound in Medicine . J Ultrasound Med. 2013;32:609-16. 